\title{
BK channel opener protects cell viability by regulating reactive oxygen levels in astrocyte cells
}

\author{
Cagil Coskun ${ }^{1}$ and Onur Tokgun ${ }^{2}$ \\ ${ }^{1}$ Department of Biophysics, Faculty of Medicine, Cukurova University, Adana, Turkey \\ ${ }^{2}$ Medical Genetics, Faculty of Medicine, Pamukkale University, Denizli, Turkey
}

\begin{abstract}
Astrocytes are greatly impacted by oxidative stress, which can also be related to neurodegenerative diseases. Therefore, preventing the production of reactive oxygen species (ROS) is crucial for maintaining healthy cells. Large conductance $\mathrm{Ca}^{2+}$-activated big potassium (BK) channel openers are effective in eliminating the effects of oxidative stress. The present study aims to determine if NS11021, a BK channel opener, protects the astrocytes from harmful effects of hydrogen peroxide $\left(\mathrm{H}_{2} \mathrm{O}_{2}\right)$, which is an oxidative stress inducer. For this purpose, primary astrocyte cultures were incubated with $\mathrm{H}_{2} \mathrm{O}_{2}$, NS11021, and Iberiotoxin both separately and together. $\mathrm{H}_{2} \mathrm{O}_{2}$ decreased cell viability by approximately $50 \%$ and increased the number of ROS-positive astrocytes. However, NS11021, but not Iberiotoxin, reversed the deleterious effects of $\mathrm{H}_{2} \mathrm{O}_{2}$ on cell viability and decreased ROS production. Moreover, dysregulations in Cyclin D1/CDK6/p21 gene expressions under conditions of oxidative stress were regulated again by the opener. To the best of our knowledge, this study has been the first to reveal that NS1 1021 reversed the deleterious effects of $\mathrm{H}_{2} \mathrm{O}_{2}$ on cell viability by regulating ROS production in astrocytes. Its effect may also be related to the regulation of cell cycle at the transcriptional level. NS11021 may also be used as an agent for the treatment of oxidative-stress related dysfunction of astrocytes.
\end{abstract}

Key words: Astrocytes - BK channels - NS11021 — Oxidative stress

\section{Introduction}

Astrocytes are one of the main and most abundant class of glial cells in the central nervous system (CNS). They play critical roles in many physiological processes, such as providing neuronal support, regulating synaptic signaling or plasticity, and mediating CNS homeostasis (Takuma et al. 2004; Kandel et al. 2013; Blanco-Suarez et al. 2017). Because of the astrocytic endfeet structure, they also notably control the cerebrovascular tone and cerebral blood flow as well as contribute to the formation and maintenance of a healthy blood-brain barrier (Abbott et al. 2006; Gordon et al. 2007,

Electronic supplementary material. The online version of this article (doi: 10.4149/gpb_2021023) contains Supplementary material.

Correspondence to: Cagil Coskun, Department of Biophysics, Faculty of Medicine, Cukurova University, Balcall, Adana, Turkey E-mail: ccoskun@cu.edu.tr
2011; Howarth 2014). Given the importance of astrocytes in CNS, it is not surprising that dysfunction or impairment of astrocytes cause neurological diseases such as Alzheimer's disease (Talantova et al. 2013), Parkinson's disease (Bosson et al. 2015), Huntington's disease (Tong et al. 2014), and epilepsy (Coulter and Steinhauser 2015; Blanco-Suarez et al. 2017).

Reactive oxygen species (ROS) is normally produced during metabolic processes. However, an imbalance between defensive antioxidant mechanism and production of ROS may lead to oxidative stress, which has deleterious effects on many cells and functional defects (Dringen et al. 2005). High energy and oxygen consumption rates (i.e., approximately $20 \%$ of the total) indicate that the brain is greatly affected by oxidative stress (Chen et al. 2020). Moreover, many neurological diseases are linked to oxidative stress (Vieira de Almeida et al. 2008). Astrocytes have a more outstanding role in protecting the brain from oxidative stress damage owing

(c) The Authors 2021. This is an open access article under the terms of the Creative Commons Attribution-NonCommercial 4.0 International License (https://creativecommons.org/licenses/by-nc/4.0/), which permits non-commercial use, distribution, and reproduction in any medium, provided the original work is properly cited. 
to the secretion of antioxidant enzymes and neurotrophic factors (Takuma et al. 2004; Cabezas et al. 2019; Chen et al. 2020). Nevertheless, they are also rapidly and greatly affected by ROS (Liddell et al. 2009; Hamdi et al. 2015). Therefore, protecting astrocytes from harmful effects of oxidative stress is important to prevent dysfunctional astrocyte-related diseases as well as maintain the antioxidative mechanism of astrocytes and an optimal number of astrocytes (Amri et al. 2017).

Astrocytes contain many ion channels, exchangers, and transporters that regulate homeostasis, osmosis, and dynamic function of the CNS and blood-brain barrier (Abbott et al. 2006). The main type of channel in astrocytes is the large-conductance big potassium (BK) channel activated by either intracellular calcium concentration or membrane voltage (Seifert et al. 2018). Activation of the channel initiates a large $\mathrm{K}^{+}$efflux and leads to close voltage-gated calcium channels; it also prevents the influx of more calcium into the cells (Vetri et al. 2014). Therefore, BK channel regulates many physiological processes such as calcium and neural signaling, ion homeostasis, or hormone secretion (Ghatta et al. 2006; Yang et al. 2015). Together with the Kir (inward rectifier potassium) channels, BK channel is responsible for buffering potassium in astrocytes. Moreover, astrocytic BK channels play a bidirectional role in the regulation of cerebrovascular tone because a calcium concentration of approximately 300 $\mathrm{nm}$ in the astrocytic endfeet leads to vasodilation, whereas a higher concentration mediates vasoconstrictive movements (Kim et al. 2019). Therefore, BK channels have become a target for the therapy of diseases based on their essential roles (Kshatri et al. 2018). Moreover, the efficiency of the channel openers in eliminating oxidative stress from skeletal muscles and neurons is also demonstrated in previous studies (Yan et al. 2015; Coskun et al. 2020). However, the antioxidative role of the channel opener has not yet been studied in astrocytes. Given the importance of eliminating the effects of ROS on astrocytes, the present study aimed to determine whether NS11021, a BK channel opener, protects astrocytes against cell death caused by oxidative stress. The effect of the opener was also evaluated at transcriptional levels of the cell cycle to achieve a better resolution. Moreover, Iberiotoxin, a BK channel inhibitor, was used as an internal control to evaluate the effect of the channel on ROS-induced mechanisms in astrocyte cells.

\section{Material and Methods}

\section{Primary culture of astrocytes}

The Local Ethical Committee approved this study for Experimental Research at Pamukkale University. Five-day-old Wistar rat's brains were used for the preparation of astrocyte cell cultures by varying previously reported methods (Cole and de Vellis 2001; Becerir et al. 2013). Dissected brains were mechanically minced, separated and then passed through a nylon sieve (pore size, $70 \mu \mathrm{m}$ ) followed by centrifugation for $5 \mathrm{~min}$ at $1500 \mathrm{rpm}$. After cell collection, pellets were suspended in Dulbecco's Modified Eagle Medium/F12 (DMEM/ F12) (Biochrom, Germany), containing 10\% heat-inactivated fetal bovine serum (FBS) (Hyclone, Thermo Scientific, UK), $500 \mu$ l gentamicin $(10 \mathrm{mg} / 10 \mathrm{ml}$, Sigma-Aldrich, USA), and $5 \mathrm{ml}$ fungizone $(25 \mu \mathrm{g} / \mathrm{ml}$ amphotericin $\mathrm{B}$, Gibco Invitrogen, New York, USA). After the resuspended cells were plated on poly-d-lysine-coated $75-\mathrm{cm}^{2}$ flasks, they were incubated in steady conditions at $37^{\circ} \mathrm{C}$ with $5 \% \mathrm{CO}_{2}$; the media was changed every 3 days. After a week of culturing, other cells were detracted from the astrocyte monolayer by shaking the culture in an orbital shaker for $1 \mathrm{~h}$. Astrocyte cells were collected after 8-10 days, and cell pellets were resuspended in the astrocyte medium [DMEM/F12-containing $500 \mu \mathrm{l}$ gentamicin, $5 \mathrm{ml}$ fungizone, 15\% FBS, $5 \mathrm{ml} \mathrm{L}$-glutamine (200 mM, Gibco, Invitrogen, New York, USA), and $500 \mu \mathrm{l}$ insulin (0.5 mg/ml, Biochrom, Berlin, Germany)]. The method was estimated to given $\sim 95 \%$ astrocyte purity in cultures, and these astrocyte cell cultures were used for further experiments.

\section{Experimental design}

After preparation, cells were exposed to certain chemicals to achieve the goals of this study. $1 \mathrm{mM}$ hydrogen peroxide $\left(\mathrm{H}_{2} \mathrm{O}_{2}\right)$ was used as an oxidative stress inducer. While the dose of $\mathrm{H}_{2} \mathrm{O}_{2}$ was chosen by considering the previous studies measuring similar experimental parameters (Terashvili et al. 2012), the exposure time of the chemical was determined by analyzing the effect of $\mathrm{H}_{2} \mathrm{O}_{2}$ on cell viability at different time points of 30,60 , and $120 \mathrm{~min}$.

After determining the application dose and time period for $\mathrm{H}_{2} \mathrm{O}_{2}$ exposure, the cells were separately treated for 30 , 60 , and 120 min with $3 \mu \mathrm{M}$ NS11021 (NS11021 group), $3 \mu \mathrm{M}$ NS11021 following $1 \mathrm{mM} \mathrm{H} \mathrm{O}_{2}$ ( $\mathrm{NS} 11021+\mathrm{H}_{2} \mathrm{O}_{2}$ group), $50 \mathrm{nM}$ Iberiotoxin (IbTx group), and $50 \mathrm{nM}$ Iberiotoxin following $1 \mathrm{mM} \mathrm{H}_{2} \mathrm{O}_{2}$ ( $\mathrm{IbTx}+\mathrm{H}_{2} \mathrm{O}_{2}$ group). In the present study, Iberiotoxin was also used to evaluate if $\mathrm{H}_{2} \mathrm{O}_{2}$ affects BK channels.

\section{Evaluation of cytotoxic effect of chemicals}

To determine the toxicity of $\mathrm{H}_{2} \mathrm{O}_{2}$, we subjected the cells to $\mathrm{H}_{2} \mathrm{O}_{2}$ treatment for different time periods $(30,60$, and $120 \mathrm{~min})$. After the incubation period, the medium was removed and cells were incubated with a fresh medium. To evaluate the possible proliferative effects of NS11021 and Iberiotoxin, we treated the cells with NS11021 (3 $\mu \mathrm{M})$ and Iberiotoxin $(50 \mathrm{nM})$ for 60 and $120 \mathrm{~min}$, respectively, after 
$\mathrm{H}_{2} \mathrm{O}_{2}$ treatment (60 min). Additionally, we treated the cells separately with NS11021 and Iberiotoxin for 60 and $120 \mathrm{~min}$. For all cell viability experiments, $3 \times 10^{4}$ cells were seeded in each 96-well plate. Cell survival was analyzed using Cell Counting Kit-8 (Boster Bio, USA). The absorbance was measured at $450 \mathrm{~nm}$ using a Promega Glomax multi-detection microplate reader (Promega, USA). The absorbance values obtained were used to calculate the percentage of cell viability using the formula $100 \times \mathrm{A} 1 / \mathrm{A} 0$, where $\mathrm{A} 1$ (incubation hour) and $\mathrm{A} 0\left(0^{\text {th }}\right.$ hour $)$ are the absorbance values of treated and control cells, respectively.

\section{ROS detection}

According to the manufacturer protocol, intracellular ROS levels were evaluated using the Cellular ROS/RNS Detection Assay Kit (Abcam, USA). Briefly, cells were plated onto a 24-well plate, and following the treatments, cells were captured under a fluorescence microscope at 490-650 nm. The fluorescence-positive cells were measured using the ImageJ program.

\section{Real-time PCR}

In the present study, the effects of $\mathrm{H}_{2} \mathrm{O}_{2}, \mathrm{BK}$ channel activator, and inhibitor on the cell cycle of astrocyte cells, which are critical for maintaining cell viability were also investigated at the transcriptional level to obtain detailed molecular information. For this purpose, the gene expression levels of Cyclin D1, CDK6, p21, which are some of the most critical regulators at the G1 checkpoint, in the treated cells were determined by performing real-time PCR experiments. For this purpose, astrocyte cell lines were seeded into 6-well plates. At the end of the incubation period, total RNA was extracted using $500 \mu \mathrm{l}$ Trizol reagent (Qiagen, Germany). After RNA was harvested from the cells, cDNA was synthesized using the High Capacity cDNA Reverse Transcription kit (Applied Biosystems, Foster City, CA, USA). The qRT-PCR reaction was performed on the Bio-Rad CFX-96 device using 2×SYBR green (QuantiTect, Qaigen) master mix. Primers used in real-time PCR experiments are shown in Table 1.

Table 1. Primers used in the Real-time PCR experiments

\begin{tabular}{ll}
\hline & Sequences (5'>3') \\
\hline CDK6 Forward & TTGTGACAGACATCGACGAG \\
CDK6 Reverse & GACAGGTGAGAATGCAGGTT \\
Cyclin D1 Forward & CAGACCAGCCTAACAGATTTC \\
Cyclin D1 Reverse & TGACCCACAGCAGAAGAAG \\
p21 Forward & AGTATGCCGTCGTCTGTTCG \\
p21 Reverse & GAGTGCAAGACAGCGACAAG \\
\hline
\end{tabular}

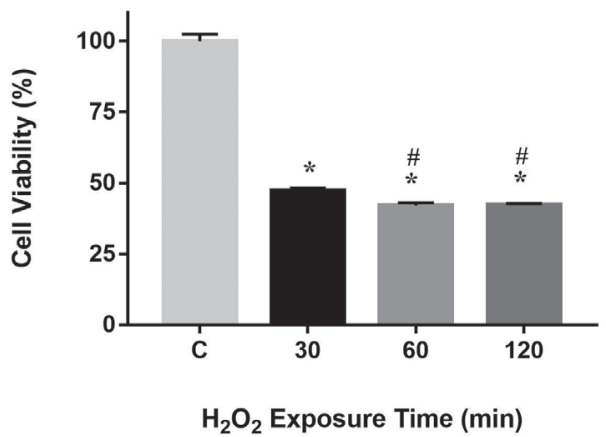

Figure 1. The cell viability (\%) of astrocytes after treatment with $\mathrm{H}_{2} \mathrm{O}_{2}$ for 30,60 , and 120 min. Data (mean $\pm \mathrm{SD}, n=3$ ) are provided by normalizing the cell numbers with the control cell numbers. ${ }^{*} p<0.05 v$ s. Control (C) group, ${ }^{\#} p<0.05 v s .30 \mathrm{~min}_{2} \mathrm{O}_{2}$-treated group (one-way ANOVA followed by post hoc Tukey's test).

\section{Statistical analysis}

Here, one-way ANOVA and post-hoc Tukey's tests were performed to determine any difference between groups. Statistical analyses were conducted using GraphPad Prism (Graphpad Software, San Diego, CA, USA).

\section{Results}

In the present study, the cell viability of astrocytes in the presence of $1 \mathrm{mM} \mathrm{H}_{2} \mathrm{O}_{2}$ is demonstrated in Figure 1. At each exposure time, $\mathrm{H}_{2} \mathrm{O}_{2}$-induced cell death was $>50 \%$ in comparison with the control (47.22 $\pm 1.06 \% ; 42.13 \pm 0.94 \%$; $42.34 \pm 0.45 \%$ for 30,60 , and $120 \mathrm{~min}$, respectively). When the groups were compared using one-way ANOVA, astrocyte cell viability after $30-$ min $\mathrm{H}_{2} \mathrm{O}_{2}$ exposure was found to be statistically different from that after 60- and 120-min $\mathrm{H}_{2} \mathrm{O}_{2}$ exposure. However, there were no significant differences between the cell viability of astrocytes subjected to 60- and 120-min $\mathrm{H}_{2} \mathrm{O}_{2}$ exposure. To avoid more harmful effects of $\mathrm{H}_{2} \mathrm{O}_{2}$ at $120 \mathrm{~min}$, which could be lethal, we chose to treat cells with $\mathrm{H}_{2} \mathrm{O}_{2}$ for $60 \mathrm{~min}$ in further experiments of this study; this decision was also reinforced by the fact that a 60 -min $\mathrm{H}_{2} \mathrm{O}_{2}$ exposure is more effective in causing cell death than a $30-$ min $\mathrm{H}_{2} \mathrm{O}_{2}$ exposure.

Figure 2 shows the effects of BK channel activator or inhibitor on cell viability of astrocyte cells in the presence or absence of $\mathrm{H}_{2} \mathrm{O}_{2}$. The viability of cells treated with NS11021 for 60 and $120 \mathrm{~min}(100.7 \pm 0.59 \%$ and $98.71 \pm 1.08 \%$, respectively) which was similar to that of control cells, was significantly different from the viability of cells treated with $\mathrm{H}_{2} \mathrm{O}_{2}$ for 60 min (Fig. 2A). Most notably, the viability of $\mathrm{H}_{2} \mathrm{O}_{2}$-treated cells with $\mathrm{BK}$ channel activator as an additive (NS11021+ $\mathrm{H}_{2} \mathrm{O}_{2}$ groups) for both 60 and $120 \mathrm{~min}$ (66.08 

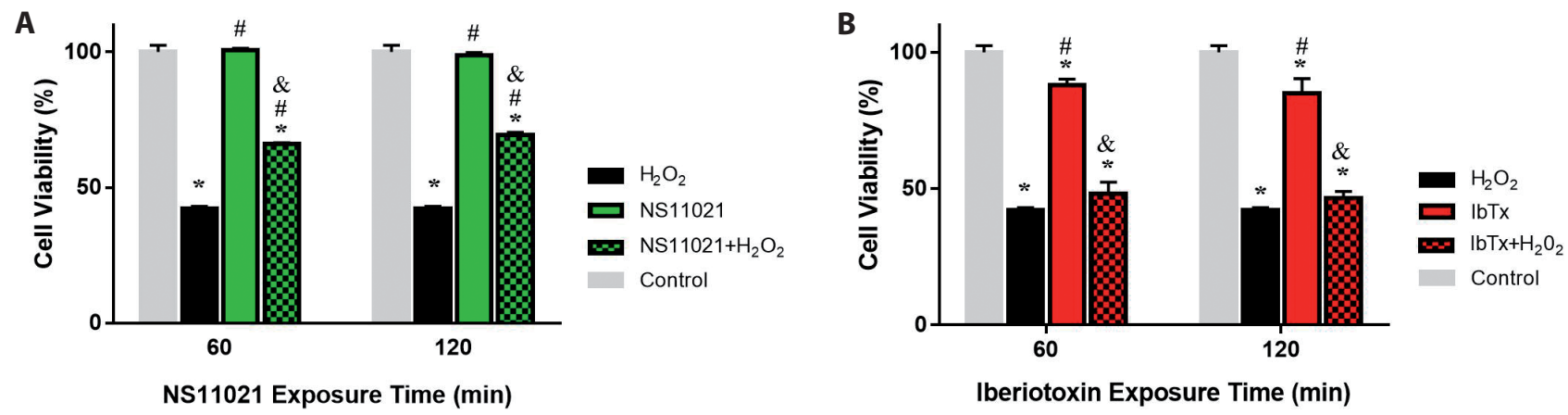

Figure 2. The viability (\%) of cells after treatment with NS11021 (A) and Iberiotoxin (B) at different exposure times. Data (mean \pm SD, $n=3$ ) are given by normalizing the cell numbers with the control cell numbers. ${ }^{*} p<0.05 v$ s. Control group, ${ }^{\#} p<0.05 v s . \mathrm{H}_{2} \mathrm{O}_{2}$-treated group, ${ }^{\&} p<0.05$ vs. NS11021 or IbTx group (one-way ANOVA followed by post hoc Tukey's test). Control and $\mathrm{H}_{2} \mathrm{O}_{2}$ groups were not treated with NS11021 or Iberiotoxin. IbTx, Iberiotoxin.

$\pm 0.43 \%$ and $69.34 \pm 1.02 \%$, respectively) was statistically higher than that of $\mathrm{H}_{2} \mathrm{O}_{2}$-treated and control groups. The viability of untreated cells significantly decreased after the addition of Iberiotoxin for 60 and $120 \mathrm{~min}(87.92 \pm 2.26 \%$ and $85.05 \pm 5.27 \%$, respectively) in a dose-dependent manner (Fig. 2B). Nevertheless, the cell viability of these groups was still significantly higher than that of the $\mathrm{H}_{2} \mathrm{O}_{2}$-treated groups. Most importantly, the viability of $\mathrm{H}_{2} \mathrm{O}_{2}$-treated cells with Iberiotoxin additive ( $\mathrm{IbTx}+\mathrm{H}_{2} \mathrm{O}_{2}$ groups) for both 60 and $120 \mathrm{~min}(48.15 \pm 4.25 \%$ and $46.47 \pm 2.54 \%$, respectively) was not statistically different from that of the $\mathrm{H}_{2} \mathrm{O}_{2}$-treated groups.

Considering that the treatment with NS11021 alone for $120 \mathrm{~min}$ is more effective in protecting cell viability than NS11021 treated with $\mathrm{H}_{2} \mathrm{O}_{2}$, and that present study aimed to investigate the efficiency of the BK channel opener, subsequent gene expression experiments were conducted using the cells subjected to chemical exposure (NS11021 or Iberiotoxin) for $120 \mathrm{~min}$.

ROS-positive cells belonging to each group are shown in Figure 3. As expected, the control group has minor ROS activity $(19.33 \pm 3.21 \%)$. With the addition of $\mathrm{H}_{2} \mathrm{O}_{2}$, about a third of four of the cell has ROS level $(75.33 \pm 7.02 \%)$ and its ROS activity were significantly different from that of control's (Fig. 3). Although the ROS activity of cells treated with NS11021 alone $(20 \pm 4.4 \%)$ was same as that seen in control cells (Fig. 3A), in comparison with the number of ROS-positive cells in the $\mathrm{H}_{2} \mathrm{O}_{2}$ group, it was found that after NS11021 addition in the NS11021 $+\mathrm{H}_{2} \mathrm{O}_{2}$ group, the number of ROS-positive cells significantly reduced by half of what it was when treated with $\mathrm{H}_{2} \mathrm{O}_{2}$ alone $(44.33 \pm 6.11 \%)$. The ROS activity of Iberiotoxin-treated cells ( $44 \pm 7 \%$ ) was significantly higher than that of the control, but not as much as that of the $\mathrm{H}_{2} \mathrm{O}_{2}$-treated cells (Fig. 3B). In particular, ROS activity was the highest in the $\mathrm{IbTx}+\mathrm{H}_{2} \mathrm{O}_{2}$ group $(86.33 \pm 4.93 \%)$ and the combined effect of Iberiotoxin and $\mathrm{H}_{2} \mathrm{O}_{2}$ on ROS activity was significant from the effect of Iberiotoxin alone but not from that of $\mathrm{H}_{2} \mathrm{O}_{2}$ treatment. Demonstrative illustrations of microscopic captions of cell viability and ROS-positive cells are provided in the Supplementary material (Fig. S1, S2 and S3).

Figure 4 demonstrates the targeted gene expression analysis of each group in the present study. Cyclin D1 gene
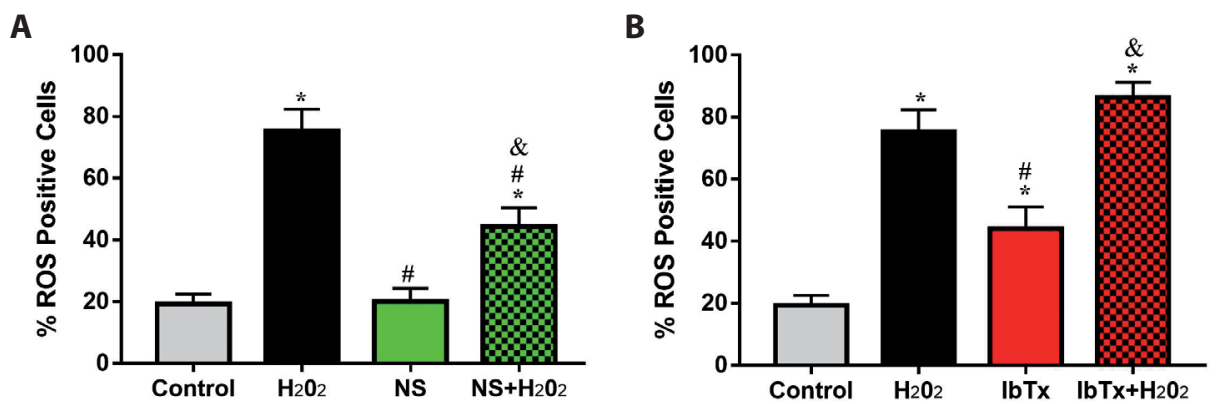

Figure 3. Percentage of ROS-positive cells after NS11021 addition (A) and Iberiotoxin addition (B). Data are the mean \pm SD, $n=3$. $^{*} p<$ 0.05 vs. Control group, ${ }^{*} p<0.05 v s . \mathrm{H}_{2} \mathrm{O}_{2}$-treated group, ${ }^{\&} p<0.05 v s$. NS11021 or IbTx group (one-way ANOVA followed by post hoc Tukey's test). Control and $\mathrm{H}_{2} \mathrm{O}_{2}$ groups were not treated with either NS11021 or Iberiotoxin. NS, NS11021; IbTx, Iberiotoxin. 
expression levels in the $\mathrm{H}_{2} \mathrm{O}_{2}$-treated group $(0.44 \pm 0.08)$ were significantly lower than those in the control group. The gene expression level in the NS11021-treated group (0.91 \pm 0.02) significantly differed from the $\mathrm{H}_{2} \mathrm{O}_{2}$ group (Fig. 4A) but not with the control group. Cyclin D1 expression level in the $\mathrm{NS} 11021+\mathrm{H}_{2} \mathrm{O}_{2}$ group $(0.78 \pm 0.15)$ was significantly higher than that in the $\mathrm{H}_{2} \mathrm{O}_{2}$ group. The addition of Iberiotoxin significantly reduced the gene expression level (0.59 \pm 0.12 ) as compared to the control's level (Fig. 4B). Moreover, both Iberiotoxin and $\mathrm{H}_{2} \mathrm{O}_{2}$-induced cells had the lowest
Cyclin D1 expression level in the $\mathrm{IbTx}+\mathrm{H}_{2} \mathrm{O}_{2}$ group $(0.10 \pm$ 0.07 ). Similar results were obtained for CDK6 gene expression levels but data were not statistically significant because of a high standard error of the mean (Fig. 4C,D). The expression level of CDK6 was reduced in $\mathrm{H}_{2} \mathrm{O}_{2}$-treated cells ( 0.59 \pm 0.15 ) when compared with that in the controls. Moreover, while NS11021 increased CDK expression (1.72 \pm 1.09$)$, Iberiotoxin reduced it $(0.70 \pm 0.45)$. When NS1 1021 was added to $\mathrm{H}_{2} \mathrm{O}_{2}$-treated cells, CDK6 expression increased to $0.70 \pm$ 0.19 compared to $\mathrm{H}_{2} \mathrm{O}_{2}$. However, $\mathrm{IbTx}+\mathrm{H}_{2} \mathrm{O}_{2}$ dramatically
A

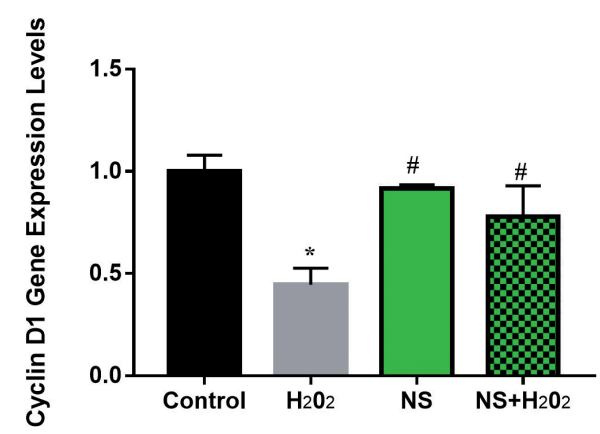

C

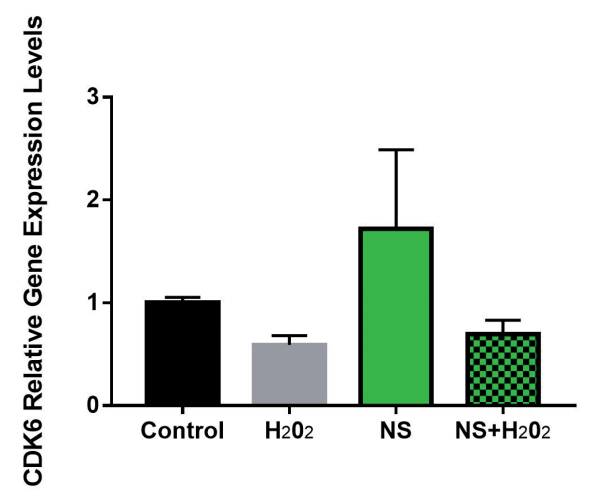

E

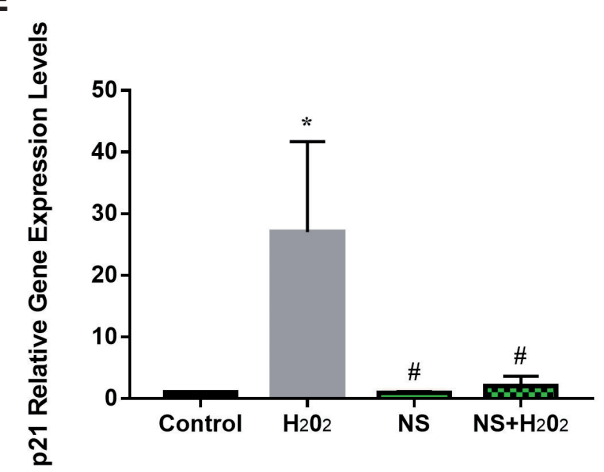

B

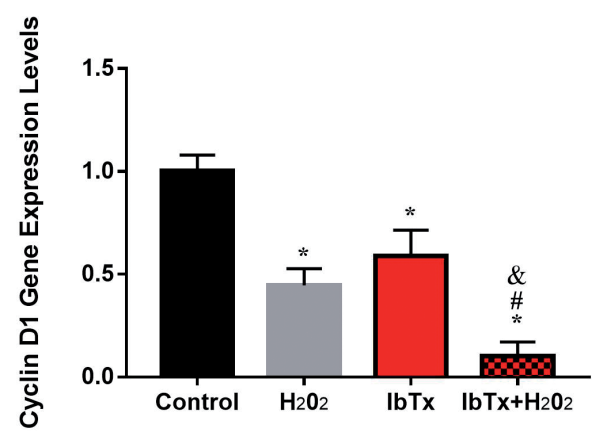

D

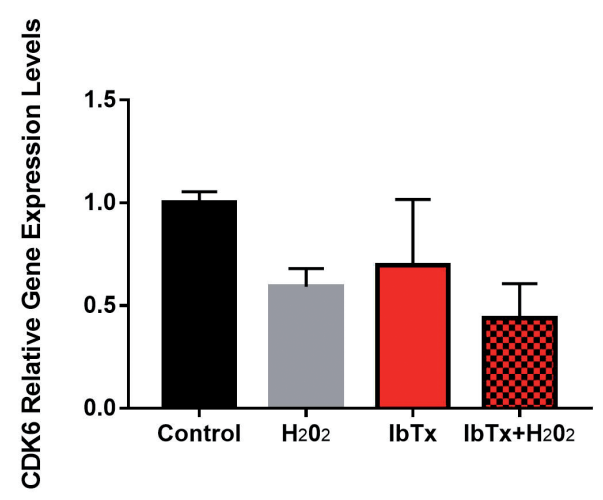

$\mathbf{F}$

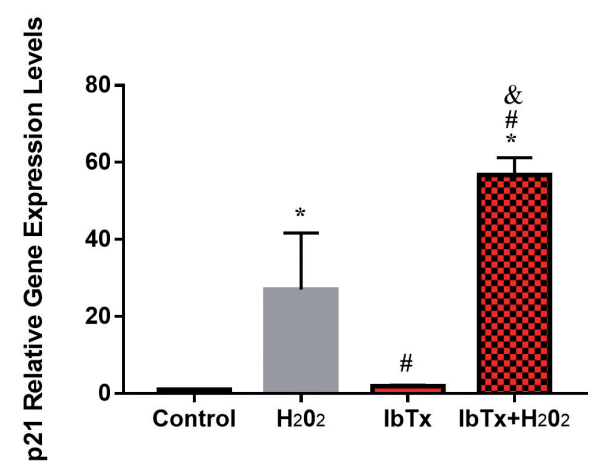

Figure 4. Gene expression levels of the targeted genes Cyclin D1 (A, B), CDK6 (C, D) and p21 (E, F) in the groups treated with $\mathrm{H}_{2} \mathrm{O}_{2}$, NS11021 (left) or Iberiotoxin (right). Data are the mean $\pm \mathrm{SD}, n=3 .{ }^{*} p<0.05$ vs. Control group, ${ }^{\#} p<0.05 v s$. $\mathrm{H}_{2} \mathrm{O}_{2}$-treated group, ${ }^{\circledR} p<$ 0.05 vs. IbTx group (one-way ANOVA followed by post hoc Tukey’s test). NS, NS11021; IbTx, Iberiotoxin. 
decreased its expression to $0.44 \pm 0.24$. On evaluating $\mathrm{p} 21$ gene expression levels between groups, it was found that the gene transcriptional level significantly increased in the $\mathrm{H}_{2} \mathrm{O}_{2}$ group $(27.04 \pm 14.65)$ in comparison with the gene transcriptional level in the control (Fig. 4E,F). Although p21 levels in the NS11021 and $\mathrm{NS} 11021+\mathrm{H}_{2} \mathrm{O}_{2}$ groups $(0.91 \pm$ 0.23 and $2.07 \pm 1.56$, respectively) were not significantly different from the $\mathrm{p} 21$ level in the control, they significantly differed from the p21 level in the $\mathrm{H}_{2} \mathrm{O}_{2}$ group. Iberiotoxininduced cells had a slightly increased p 21 gene expression level $(1.87 \pm 0.34)$; however, this increase was not statistically significant. Notably, both Iberiotoxin and $\mathrm{H}_{2} \mathrm{O}_{2}$ mostly and significantly increased the p21 level (56.68 \pm 4.58$)$.

\section{Discussion}

With regard to oxygen consumption, the brain is one of the tissues most affected by ROS (Chen et al. 2020). Astrocyte cells, which possess defensive mechanisms against ROS, can also be easily affected by ROS. Additionally, since many neurological diseases are known to be associated with astrocytes, it is crucial to eliminate excessive ROS production to maintain a healthy antioxidative defense mechanism and prevent dysfunctional astrocyte-related disorders that can be caused by excess ROS (Amri et al. 2017; Chen et al. 2020). BK ion channels play an important role in regulating and homeostasis among many cells, including astrocytes (Yang et al. 2015; Seifert et al. 2018). Moreover, channel openers that activate the channels have been previously reported to prevent excessive ROS production in muscles and neurons (Yan et al. 2015; Coskun et al. 2020). However, to date, their effects on excessive ROS activity in astrocyte cells have not yet been demonstrated. The present study evaluated the action of NS11021, an effective BK channel opener, on ROS production in astrocytes; to our knowledge, the present study is the first to report that NS11021 reversed the deleterious effect of $\mathrm{H}_{2} \mathrm{O}_{2}$ on astrocyte cell viability in a time-dependent manner.

$\mathrm{H}_{2} \mathrm{O}_{2}$ is an ROS as well as a cell death inducer, and its effect at different concentrations and different exposure times has been frequently studied among various cells, including astrocytes. $\mathrm{H}_{2} \mathrm{O}_{2}$ has previously been used to induce astrocyte cell death at a concentration range between 0.1-1200 $\mu \mathrm{M}$ (Gorina et al. 2005; Kim et al. 2005; Choi et al. 2007; Terashvili et al. 2012). Based on a previous study (Gorina et al.2005), it appears that the dose and application time of $\mathrm{H}_{2} \mathrm{O}_{2}$ which causes $>50 \%$ cell death usually tends to be chosen. A similar strategy was also followed in this study, wherein the effects of $1 \mathrm{mM} \mathrm{H}_{2} \mathrm{O}_{2}$ were evaluated at different exposure times and cell death was analyzed. Even though each exposure time showed $>50 \%$ cell viability, we chose to expose cells to $\mathrm{H}_{2} \mathrm{O}_{2}$ for $60 \mathrm{~min}$ as there was no difference between the effects induced by 60 - and 120-min exposure. The cell viability observed in this study was more or less compatible with that reported in a previous study when the same concentration of $\mathrm{H}_{2} \mathrm{O}_{2}$ was used for $60 \mathrm{~min}$; the slight difference in the percentage of cell viability reported by Gorina et al. (2005) could be owing to measurement of cell viability $24 \mathrm{~h}$ after $60-\mathrm{min} \mathrm{H}_{2} \mathrm{O}_{2}$ exposure, and this prolonged incubation period could have increased the cell death induced by an irreparable ROS-induced damage. However, in the present study, we investigated the acute effect of $\mathrm{H}_{2} \mathrm{O}_{2}$. The results of $\mathrm{H}_{2} \mathrm{O}_{2}$ incubation on ROS production in astrocyte cells strongly demonstrated that $\mathrm{H}_{2} \mathrm{O}_{2}$ induced cell death by producing ROS; here, it was seen that as the ROS level increases, cell death in astrocyte also increases.

The effects of BK channels on cell viability were reported in previous studies. Dysfunction of the channel caused by mutations or inhibitors reduced cell viability in many cells, including neurons (Du et al. 2020). On the other hand, activation of the channel helped control cell death in various diseases and inhibited the proliferation of cancer cells (Borchert et al. 2013; Wojtovich et al. 2013; Sizemore et al. 2020). Our result was compatible with the result from a previous study (Hermann et al. 2015) that NS11021treated astrocyte cells showed no significant difference from controls. In addition, activation of the channel by NS11021 also exhibited no difference in terms of ROS levels. These results might be important because the channel activators are targeted in various tissues, especially for muscle diseases such as periodic paralysis (Tricarico and Camerino 2011). It is also crucial that the use of channel activators to treat other tissue diseases does not cause any adverse effects on astrocytes with regard to cell death.

The most noteworthy result of this study was that NS11021 prevents $\mathrm{H}_{2} \mathrm{O}_{2}$-induced cell death in astrocytes. Moreover, the effect was dependent on the dose, i.e., a 120min exposure of NS11021 was more effective in preventing cell death than a 60-min exposure. Even some previous studies showed the cryoprotective effects of NS11021 on pathological processes such as ischemia/reperfusion models (Borchert et al. 2013; Wojtovich et al. 2013), and a few studies showed how this channel opener could protect neuronal cells from oxidative stress conditions during the cell cycle (Gaspar et al. 2008; Yan et al. 2015); to the best of our knowledge, this study reported for the first time that NS11021 protects the viability of astrocytes under $\mathrm{H}_{2} \mathrm{O}_{2}$-induced oxidative stress conditions. On the other hand, when NS11021 was added to the cells that had already been exposed to $\mathrm{H}_{2} \mathrm{O}_{2}$, the number of ROS-positive cells was significantly lesser in the $\mathrm{NS} 11021+\mathrm{H}_{2} \mathrm{O}_{2}$ group than that in the $\mathrm{H}_{2} \mathrm{O}_{2}$ group. When these two results are evaluated together, it can be clearly elucidated that NS11021 exerts its protective effect on cells against oxidative stress by reducing ROS production. This 
finding is also compatible with that of a previous study in which NS11021 was observed to exert its protective effect on neurons by decreasing ROS and exhibiting an antioxidative defense mechanism (Yan et al. 2015). On the other hand, because ROS is produced during normal physiological processes, it was expected to be produced in control cells (Forrester et al. 2018).

The correlation between cell death caused by Iberiotoxininduced inhibition of BK channels and the increase in ROS level in the cells incubated with Iberiotoxin demonstrated that BK channels play a role in ROS-induced cell death of astrocytes. The result is also demonstrating the importance of targeting BK channels for eliminating the deleterious effects of oxidative stress conditions on astrocytes.

The cell cycle is controlled at certain checkpoints which determine if genome synthesis should continue or be stopped to begin cell division (Reece et al. 2014). Cyclin-dependent kinases, inhibitors, or growth factors play key roles in the regulation of these processes. One of the main checkpoints is at the G1 phase which determines whether the cell would enter the cycling processes or return to G0. Cyclin D1 and its dependent kinases, CDK6 and CDK4, are responsible for regulating the cell cycle and for controlling progression to the G1 checkpoint. On the other hand, cyclin-dependent kinase inhibitors $\left(\mathrm{CDK}_{1}\right)$ regulate the cell cycle by binding specific kinases and suppressing its dependent kinase activity. Furthermore, p21 is one of the main CDK1 which is usually active in response to DNA damage (Alberts et al. 2008). Exposure to external stimuli such as reactive oxygen species or radiation causes disruption of the cell cycle which in turn dysregulates the expression of Cyclin D1, CDK6, and p21 expression similar to other cyclin-dependent complexes (Kaneto et al. 1999; Masgras et al. 2012; Pyo et al. 2013). Therefore, re-regulation of the cyclic elements is essential for maintaining a healthy cell. Previous studies have shown that oxidative stress induced by $\mathrm{H}_{2} \mathrm{O}_{2}$ reduced and downregulated Cyclin D1 level in mammalian cells (Alao 2007; Pyo et al. 2013). In a similar manner, $\mathrm{p} 21$ expression increased in oxidative stress-induced pancreatic cells (Kaneto et al. 1999). In accordance with the data available in the literature, in the present study, we found that Cyclin D1 and CDK6 were downregulated, whereas p21 was upregulated after peroxide induction. Potassium ion flux throughout $\mathrm{K}^{+}$ion channels plays a prominent role in the proliferation of cells and regulation of the cell cycle, although its mechanism of action remains unclear (Urrego et al. 2014). The channels hyperpolarize the membrane potential at G1 phase of the cell (Urrego et al. 2014). Moreover, potassium channel blockers inhibit cell cycle progression (Abdul Kadir et al. 2018). The clear correlation between the channels and cell cycle previously indicated that the inhibition of potassium channels increases p21 expression and arrests the glial cells in the G1 phase (Ghiani et al. 1999). Here, inhibition of the BK channel by Iberiotoxin decreased Cyclin D1 and CDK6 levels and increased p21 level. Therefore, this result, which is similar to the findings reported in the literature, may demonstrate that inhibition of the channel blocks cell cycle in the G1/S phase, induces apoptotic pathway via p21 accumulation, and decreases cell viability. These results clearly demonstrated that BK channels play an important role in cell cycle regulation and proliferation mediated by Cyclin D1/CDK/p21 pathway. NS11021, but not Iberiotoxin, reversed the effects of $\mathrm{H}_{2} \mathrm{O}_{2}$ on the expression of Cyclin D1/CDK6/p21 and reregulated the transcriptional levels of these genes to resemble their expression in control cells. Therefore, it can be said that NS11021 may show its protective role against oxidative stress on cell viability by regulating the cell cycle process at the transcriptional level in the G1/S phase; however, this finding needs to be further validated by performing experiments at protein levels to elucidate an exact mechanism.

In conclusion, all results were evaluated together, and the importance and role of BK channels as well as theirs openers in astrocyte cells under oxidative stress conditions was demonstrated for the first time in the present study. Moreover, the BK channel opener protects cells from oxidative stress by reducing ROS production. The effects of the opener may also be a result of the regulation of crucial elements at the transcriptional level during G1/S transition. Therefore, it can be concluded that BK channel openers can be used as a therapeutic agent for maintaining cell viability of astrocytes and exerting antioxidative mechanism in order to manage oxidative stress-related diseases.

Conflict of interest. The authors have no conflicts of interest to declare.

\section{References}

Abbott NJ, Ronnback L, Hansson E (2006): Astrocyte-endothelial interactions at the blood-brain barrier. Nat. Rev. Neurosci. 7, 41-53 https://doi.org/10.1038/nrn1824

Abdul Kadir L, Stacey M, Barrett-Jolley R (2018): Emerging roles of the membrane potential: action beyond the action potential. Front. Physiol. 9, 1661 https://doi.org/10.3389/fphys.2018.01661

Alao JP (2007): The regulation of cyclin D1 degradation: roles in cancer development and the potential for therapeutic invention. Mol. Cancer 6, 24 https://doi.org/10.1186/1476-4598-6-24

Alberts B, Johnson A, Wilson JH, Lewis J, Hunt T, Roberts K, Raff M, Walter P (2008): Molecular Biology of the Cell. Garland Science, New York https://doi.org/10.1201/9780203833445

Amri F, Ghouili I, Amri M, Carrier A, Masmoudi-Kouki O (2017): Neuroglobin protects astroglial cells from hydrogen peroxideinduced oxidative stress and apoptotic cell death. J. Neurochem. 140, 151-169 
https://doi.org/10.1111/jnc.13876

Becerir C, Kilic I, Sahin O, Ozdemir O, Tokgun O, Ozdemir B, Akca $\mathrm{H}$ (2013): The protective effect of docosahexaenoic acid on the bilirubin neurotoxicity. J. Enzyme Inhib. Med. Chem. 28, 801-807 https://doi.org/10.3109/14756366.2012.684053

Blanco-Suarez E, Caldwell AL, Allen NJ (2017): Role of astrocytesynapse interactions in CNS disorders. J. Physiol. 595, 1903-1916 https://doi.org/10.1113/JP270988

Borchert GH, Hlavackova M, Kolar F (2013): Pharmacological activation of mitochondrial $\mathrm{BK}(\mathrm{Ca})$ channels protects isolated cardiomyocytes against simulated reperfusion-induced injury. Exp. Biol. Med. (Maywood) 238, 233-241 https://doi.org/10.1177/1535370212474596

Bosson A, Boisseau S, Buisson A, Savasta M, Albrieux M (2015): Disruption of dopaminergic transmission remodels tripartite synapse morphology and astrocytic calcium activity within substantia nigra pars reticulata. Glia 63, 673-683 https://doi.org/10.1002/glia.22777

Cabezas R, Baez-Jurado E, Hidalgo-Lanussa O, Echeverria V, Ashrad GM, Sahebkar A, Barreto GE (2019): Growth factors and neuroglobin in astrocyte protection against neurodegeneration and oxidative stress. Mol. Neurobiol. 56, 2339-2351 https://doi.org/10.1007/s12035-018-1203-9

Chen Y, Qin C, Huang J, Tang X, Liu C, Huang K, Xu J, Guo G, Tong A, Zhou L (2020): The role of astrocytes in oxidative stress of central nervous system: A mixed blessing. Cell Prolif. 53, e12781 https://doi.org/10.1111/cpr.12781

Choi JJ, Choi J, Kang CD, Chen X, Wu CF, Ko KH, Kim WK (2007): Hydrogen peroxide induces the death of astrocytes through the down-regulation of the constitutive nuclear factor-kappaB activity. Free Radic. Res. 41, 555-562 https://doi.org/10.1080/10715760601173010

Cole R, de Vellis J (2001): Preparation of astrocyte, oligodendrocyte, and microglia cultures from primary rat cerebral cultures. In: Protocols for Neural Cell Culture. (Eds. Fedoroff S, Richardson A), pp. 117-127, Humana Press, Totowa, NJ, USA https://doi.org/10.1385/1-59259-207-4:117

Coskun C, Buyuknacar HS, Cicek F, Gunay I (2020): BK channel openers NS1619 and NS11021 reverse hydrogen peroxideinduced membrane potential changes in skeletal muscle. J. Recept. Signal. Transduct Res. 40, 449-455 https://doi.org/10.1080/10799893.2020.1756324

Coulter DA, Steinhauser C (2015): Role of astrocytes in epilepsy. Cold Spring Harb. Perspect. Med. 5, a022434 https://doi.org/10.1101/cshperspect.a022434

Dringen R, Pawlowski PG, Hirrlinger J (2005): Peroxide detoxification by brain cells. J. Neurosci. Res. 79, 157-165 https://doi.org/10.1002/jnr.20280

Du X, Carvalho-de-Souza JL, Wei C, Carrasquel-Ursulaez W, Lorenzo Y, Gonzalez N, Kubota T, Staisch J, Hain T, Petrossian N, et al. (2020): Loss-of-function BK channel mutation causes impaired mitochondria and progressive cerebellar ataxia. Proc. Natl. Acad. Sci. USA 117, 6023-6034 https://doi.org/10.1073/pnas.1920008117

Forrester SJ, Kikuchi DS, Hernandes MS, Xu Q, Griendling KK (2018): Reactive oxygen species in metabolic and inflammatory signaling. Circ. Res. 122, 877-902
https://doi.org/10.1161/CIRCRESAHA.117.311401

Gaspar T, Katakam P, Snipes JA, Kis B, Domoki F, Bari F, Busija DW (2008): Delayed neuronal preconditioning by NS1619 is independent of calcium activated potassium channels. J. Neurochem. 105, 1115-1128 https://doi.org/10.1111/j.1471-4159.2007.05210.x

Ghatta S, Nimmagadda D, Xu X, O'Rourke ST (2006): Largeconductance, calcium-activated potassium channels: structural and functional implications. Pharmacol. Ther. 110, 103-116 https://doi.org/10.1016/j.pharmthera.2005.10.007

Ghiani CA, Yuan X, Eisen AM, Knutson PL, DePinho RA, McBain CJ, Gallo V (1999): Voltage-activated K+ channels and membrane depolarization regulate accumulation of the cyclindependent kinase inhibitors p27(Kip1) and p21(CIP1) in glial progenitor cells. J. Neurosci. 19, 5380-5392 https://doi.org/10.1523/JNEUROSCI.19-13-05380.1999

Gordon GR, Howarth C, MacVicar BA (2011): Bidirectional control of arteriole diameter by astrocytes. Exp. Physiol. 96, 393-399

https://doi.org/10.1113/expphysiol.2010.053132

Gordon GR, Mulligan SJ, MacVicar BA (2007): Astrocyte control of the cerebrovasculature. Glia 55, 1214-1221 https://doi.org/10.1002/glia.20543

Gorina R, Petegnief V, Chamorro A, Planas AM (2005): AG490 prevents cell death after exposure of rat astrocytes to hydrogen peroxide or proinflammatory cytokines: involvement of the Jak2/STAT pathway. J. Neurochem. 92, 505-518 https://doi.org/10.1111/j.1471-4159.2004.02878.x

Hamdi Y, Kaddour H, Vaudry D, Leprince J, Zarrouk A, Hammami M, Vaudry H, Tonon MC, Amri M, Masmoudi-Kouki O (2015): Octadecaneuropeptide ODN prevents hydrogen peroxide-induced oxidative damage of biomolecules in cultured rat astrocytes. Peptides 71, 56-65 https://doi.org/10.1016/j.peptides.2015.06.010

Hermann A, Sitdikova GF, Weiger TM (2015): Oxidative stress and maxi calcium-activated potassium (bk) channels. Biomolecules 5, 1870-1911 https://doi.org/10.3390/biom5031870

Howarth C (2014): The contribution of astrocytes to the regulation of cerebral blood flow. Front. Neurosci. 8, 103 https://doi.org/10.3389/fnins.2014.00103

Kandel ER, Mack S, Jessell TM, Schwartz JH, Siegelbaum SA, Hudspeth AJ (2013): Principles of Neural Science (5th edition). McGraw-Hill Education

Kaneto H, Kajimoto Y, Fujitani Y, Matsuoka T, Sakamoto K, Matsuhisa M, Yamasaki Y, Hori M (1999): Oxidative stress induces p21 expression in pancreatic islet cells: possible implication in beta-cell dysfunction. Diabetologia 42, 1093-1097 https://doi.org/10.1007/s001250051276

Kim EJ, Park YG, Baik EJ, Jung SJ, Won R, Nahm TS, Lee BH (2005): Dehydroascorbic acid prevents oxidative cell death through a glutathione pathway in primary astrocytes. J. Neurosci. Res. 79, 670-679 https://doi.org/10.1002/jnr.20384

Kim Y, Par, J, Choi, YK (2019): The role of astrocytes in the central nervous system focused on bk channel and heme oxygenase metabolites: A Review. Antioxidants (Basel) 8, 121 https://doi.org/10.3390/antiox8050121 
Kshatri AS, Gonzalez-Hernandez A, Giraldez T (2018): Physiological roles and therapeutic potential of $\mathrm{Ca}(2+)$ activated potassium channels in the nervous system. Front. Mol. Neurosci. 11, 258

https://doi.org/10.3389/fnmol.2018.00258

Liddell JR, Zwingmann C, Schmidt MM, Thiessen A, Leibfritz D, Robinson SR, Dringen R (2009): Sustained hydrogen peroxide stress decreases lactate production by cultured astrocytes. J. Neurosci. Res. 87, 2696-2708 https://doi.org/10.1002/jnr.22093

Masgras I, Carrera S, de Verdier PJ, Brennan P, Majid A, Makhtar W, Tulchinsky E, Jones GDD, Roninson IB, Macip S (2012): Reactive oxygen species and mitochondrial sensitivity to oxidative stress determine induction of cancer cell death by $\mathrm{p} 21$. J. Biol. Chem. 287, 9845-9854 https://doi.org/10.1074/jbc.M111.250357

Pyo CW, Choi JH, Oh SM, Choi SY (2013): Oxidative stress-induced cyclin D1 depletion and its role in cell cycle processing. Biochim. Biophys. Acta 1830, 5316-5325 https://doi.org/10.1016/j.bbagen.2013.07.030

Reece JB, Urry LA, Cain ML, Wasserman SA, Minorsky PV, Jackson RB, Campbell NA (2014): Campbell Biology. Pearson

Seifert G, Henneberger C, Steinhauser C (2018): Diversity of astrocyte potassium channels: An update. Brain Res. Bull. 136, 26-36 https://doi.org/10.1016/j.brainresbull.2016.12.002

Sizemore G, McLaughlin S, Newman M, Brundage K, Ammer A, Martin K, Pugacheva E, Coad J, Mattes MD, Yu HG (2020): Opening large-conductance potassium channels selectively induced cell death of triple-negative breast cancer. BMC Cancer 20, 595 https://doi.org/10.1186/s12885-020-07071-1

Takuma K, Baba A, Matsuda T (2004): Astrocyte apoptosis: implications for neuroprotection. Prog. Neurobiol. 72, 111-127 https://doi.org/10.1016/j.pneurobio.2004.02.001

Talantova M, Sanz-Blasco S, Zhang X, Xia P, Akhtar MW, Okamoto S, Dziewczapolski G, Nakamura T, Cao G, Pratt et al. (2013): Abeta induces astrocytic glutamate release, extrasynaptic NMDA receptor activation, and synaptic loss. Proc. Natl. Acad. Sci. USA 110, E2518-2527

https://doi.org/10.1073/pnas.1306832110

Terashvili M, Sarkar P, Nostrand MV, Falck JR, Harder DR (2012): The protective effect of astrocyte-derived 14,15-epoxyeico- satrienoic acid on hydrogen peroxide-induced cell injury in astrocyte-dopaminergic neuronal cell line co-culture. Neuroscience 223, 68-76

https://doi.org/10.1016/j.neuroscience.2012.07.045

Tong X, Ao Y, Faas GC, Nwaobi SE, Xu J, Haustein MD, Anderson MA, Mody I, Olsen ML, Sofroniew MV, Khakh BS (2014): Astrocyte Kir4.1 ion channel deficits contribute to neuronal dysfunction in Huntington's disease model mice. Nat. Neurosci. 17, 694-703 https://doi.org/10.1038/nn.3691

Tricarico D, Camerino DC (2011): Recent advances in the pathogenesis and drug action in periodic paralyses and related channelopathies. Front. Pharmacol. 2, 8 https://doi.org/10.3389/fphar.2011.00008

Urrego D, Tomczak AP, Zahed F, Stuhmer W, Pardo LA (2014): Potassium channels in cell cycle and cell proliferation. Philos. Trans. R Soc. Lond. B Biol. Sci. 369, 20130094 https://doi.org/10.1098/rstb.2013.0094

Vetri F, Choudhury M, Pelligrino D, Sundivakkam PC (2014): BKca channels as physiological regulators: A focused review. Journal of Receptor, Ligand and Channel Research 2014, 3-13 https://doi.org/10.2147/JRLCR.S36065

Vieira de Almeida LM, Pineiro CC, Leite MC, Brolese G, Leal RB, Gottfried C, Goncalves CA (2008): Protective effects of resveratrol on hydrogen peroxide induced toxicity in primary cortical astrocyte cultures. Neurochem. Res. 33, 8-15 https://doi.org/10.1007/s11064-007-9399-5

Wojtovich AP, Nadtochi, SM, Urciuoli WR, Smith CO, Grunnet M, Nehrke K, Brookes PS (2013): A non-cardiomyocyte autonomous mechanism of cardioprotection involving the SLO1 BK channel. PeerJ 1, e48 https://doi.org/10.7717/peer. 48

Yan XH, Guo XY, Jiao FY, Liu X, Liu Y (2015): Activation of largeconductance $\mathrm{Ca}(2+)$-activated $\mathrm{K}(+)$ channels inhibits glutamate-induced oxidative stress through attenuating ER stress and mitochondrial dysfunction. Neurochem. Int. 90, 28-35 https://doi.org/10.1016/j.neuint.2015.07.004

Yang H, Zhang G, Cui, J (2015): BK channels: multiple sensors, one activation gate. Front. Physiol. 6, 29 https://doi.org/10.3389/fphys.2015.00029

Received: April 19, 2021

Final version accepted: July 9, 2021 


\section{BK channel opener protects cell viability by regulating reactive oxygen levels in astrocyte cells}

Cagil Coskun $^{1}$ and Onur Tokgun ${ }^{2}$

${ }^{1}$ Department of Biophysics, Faculty of Medicine, Cukurova University, Adana, Turkey

${ }^{2}$ Medical Genetics, Faculty of Medicine, Pamukkale University, Denizli, Turkey

Supplementary Figures

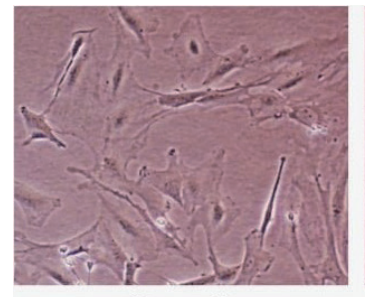

Control

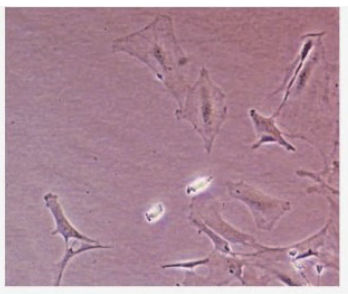

$\mathrm{H} 202$

$30 \mathrm{~min}$

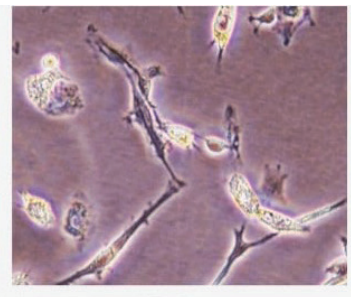

$\mathrm{H} 202$

$60 \mathrm{~min}$

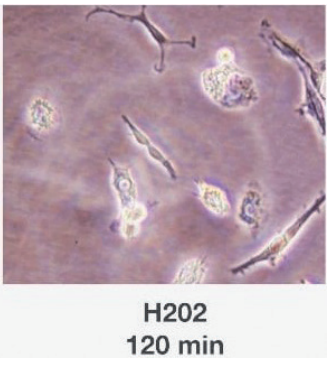

$120 \mathrm{~min}$
Figure S1. Representative microscopic captions $(10 \times$ magnification) of astrocytes in the groups.

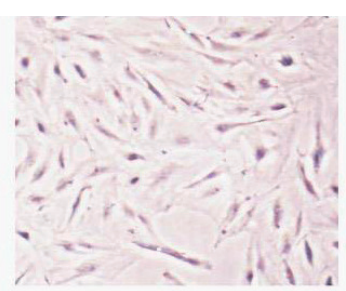

Control

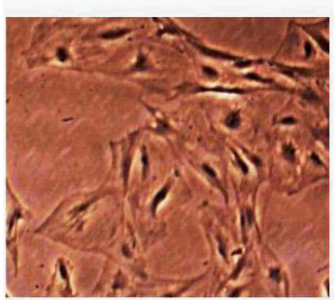

NS11021

$60 \mathrm{~min}$

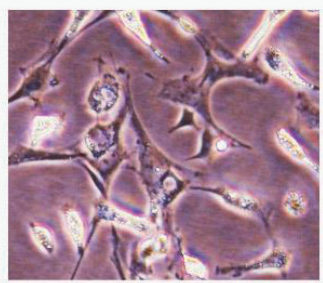

$\mathrm{lbTx}$ $60 \mathrm{~min}$

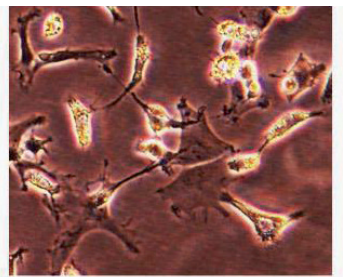

H202

$60 \mathrm{~min}$

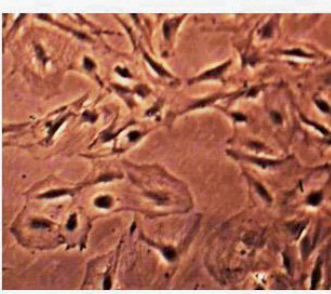

NS11021

$120 \mathrm{~min}$

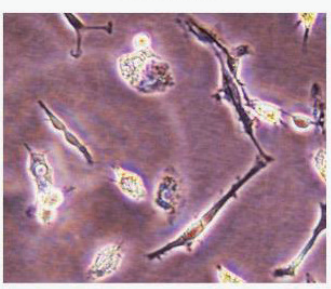

$\mathrm{IbTx}$

$120 \mathrm{~min}$

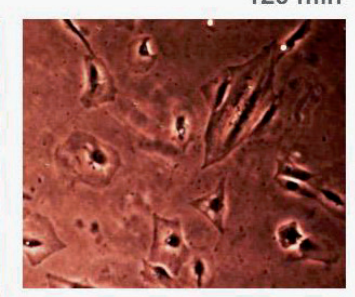

NS11021+H202

$60 \mathrm{~min}$

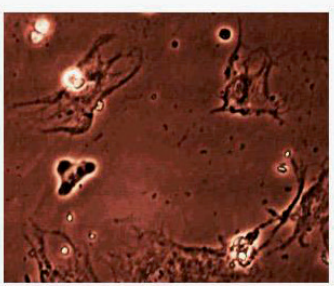

$\mathrm{IbTx}+\mathrm{H} 202$

$60 \mathrm{~min}$

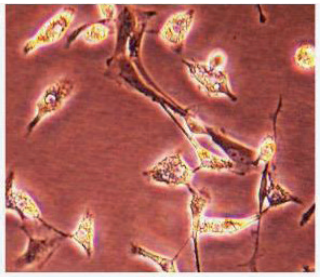

H2O2

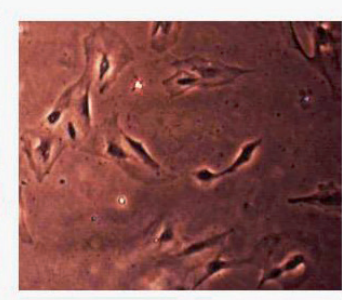

NS11021+H202 $120 \mathrm{~min}$

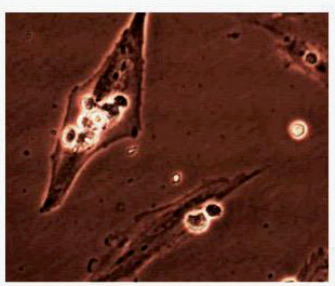

$\mathrm{IbTx}+\mathrm{H} 202$ $120 \mathrm{~min}$
Figure S2. Representative cellular morphologies of treated and control astrocyte cells under the inverted microscope (10× magnification). 


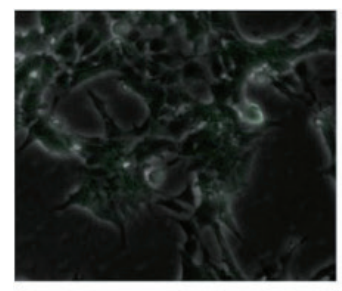

Control

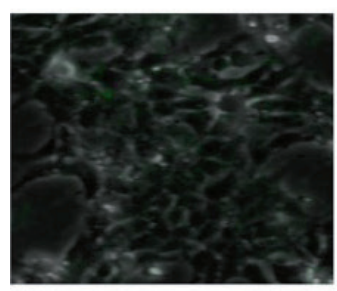

Control

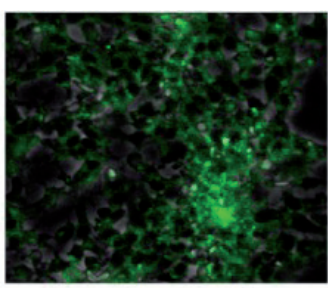

H202

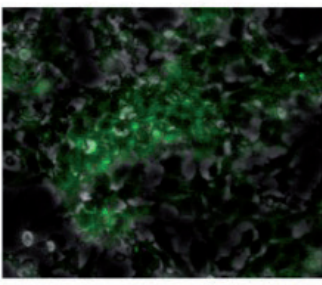

H202

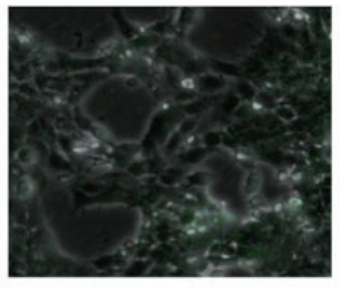

NS11021

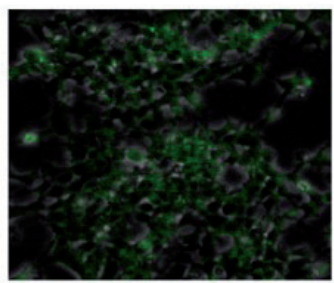

lbTx

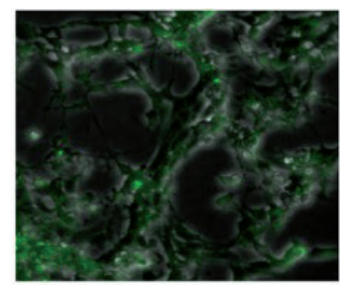

NS11021+H202

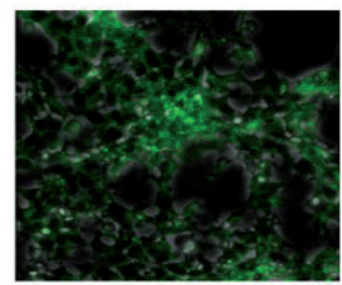

lbTx+H2O2
Figure S3. Representative flourescent images (20× magnification) of astrocytes in the groups. 